\title{
CLIMATOLOGICAL AND PHOTOGRAMMETRIC SPECULATIONS ON MASS-BALANCE CHANGES OF MCGALI, GLACIER, BROOKS RANGE, ALASKA
}

\author{
By Egon Dorrer * \\ (Department of Surveying Engineering, University of New Brunswick, Fredericton, New \\ Brunswick, Canada) \\ and Gerd Wendler \\ (Geophysical Institute, University of Alaska, Fairbanks, Alaska 9970 I, U.S.A.)
}

\begin{abstract}
The mean mass balance of the McCall Glacier, Brooks Range, Alaska, was estimated for the period $195^{8}$ to 1971 . The three methods used, photogrammetry, mean height of the equilibrium line, and correlation with the height of the synoptic 500 mbar pressure level, all gave negative values, but the amount depended on the method used. This trend of glacier recession is in agreement with most observations of glaciers in the Brooks Range as well as with the majority of the glaciers in the Northern Hemisphere.

RÉsumé. Considerations climatologiques et photogrammétriques sur les changements du bilan de masse du McCall Glacier, Brooks Range, Alaska. On a estimé le bilan de masse moyen du McCall Glacier, dans le Brooks Range en Alaska pour la période $195^{8}$ à 1971 . Les trois méthodes utilisées, photogrammétrie, altitude moyenne de la ligne d'équilibre, et corrélation avec l'altitude de l'isobare synoptique 500 mbar, ont toutes donné des valeurs négatives, mais l'importance du déficit varie avec la méthode utilisée. Cette tendance au recul du glacier concorde avec la plupart des observations des glaciers du Brooks Range, aussi bien que de la majorité des glaciers de l'hémisphère nord.

Zusammenfassung. Klimatologische und photogrammetrische Beobachtungen zu Massenhaushaltsänderungen des McCall-Glaciers, Brooks Range, Alaska. Für den Zeitraum von 1958 bis 1971 wurde der mittlere Massenhaushalt des McCall-Glaciers in der Brooks-Range, Alaska, abgeschätzt. Die drei benutzten Methoden, nämlich Photogrammetrie, mittlere Höhe der Gleichgewichtslinie und Beziehund zur Höhe des synoptischen 500 mbar-Druckniveaus, lieferten durchweg negative Werte, deren Grösse jedoch von der benutzten Methode abhing. Diese Anzeichen eines Gletscherrückganges stimmen mit den meisten Beobachtungen an den Gletschern der Brooks Range, aber auch mit denen an der Mehrzahl der Gletscher auf der Nordhemisphäre überein.
\end{abstract}

\section{Introduction}

McCall Glacier is a small glacier $\left(6.22 \mathrm{~km}^{2}\right)$ located in the Romanzof Mountains of the Brooks Range in Alaska, at lat. $69^{\circ} 18^{\prime} \mathrm{N}$., long. $143^{\circ} 48^{\prime} \mathrm{W}$. (Fig. I). It is the only Arctic glacier currently being studied in the United States, and is of special importance as it lies on two glacier "chains" recommended for intensive study in the International Hydrological Decade. These two chains are the Arctic Circle chain and the Western American chain. McCall Glacier was first studied during the I.G.Y. (Sater, I958, I959; Keeler, I959; Mason, I959; Orvig, 1961; Orvig and Mason, r 963).

The mass balance of the McCall Glacier has been measured for the hydrological years I968/1969 and r969/1970 (Wendler and others, 1972) and for 1970/1971 and 1971/1972 (Trabant and others, unpublished). However, four years of mass-balance data is a very short interval to determine general trends (e.g. Paterson, 1969), hence other methods were used to obtain mass-balance estimates for a I 5 -year period. This attempt was considered useful, since there are only very few long-term mass balance studies, most of them in lower latitudes (Schytt, I962; Hoinkes and Rudolf, I962; LaChapelle, I965; Meier and Tangborn, $1965)$.

\section{Photogrammetry}

Finsterwalder (I953) first showed that photogrammetry is a powerful tool in obtaining mass-balance changes over a long period of time. Best results are obtained, not with annual photographs, but with photographic coverage over intervals of 10 years or more. Otherwise

\footnotetext{
* Present address: Hochschule der Bundeswehr, München, West Germany.
} 


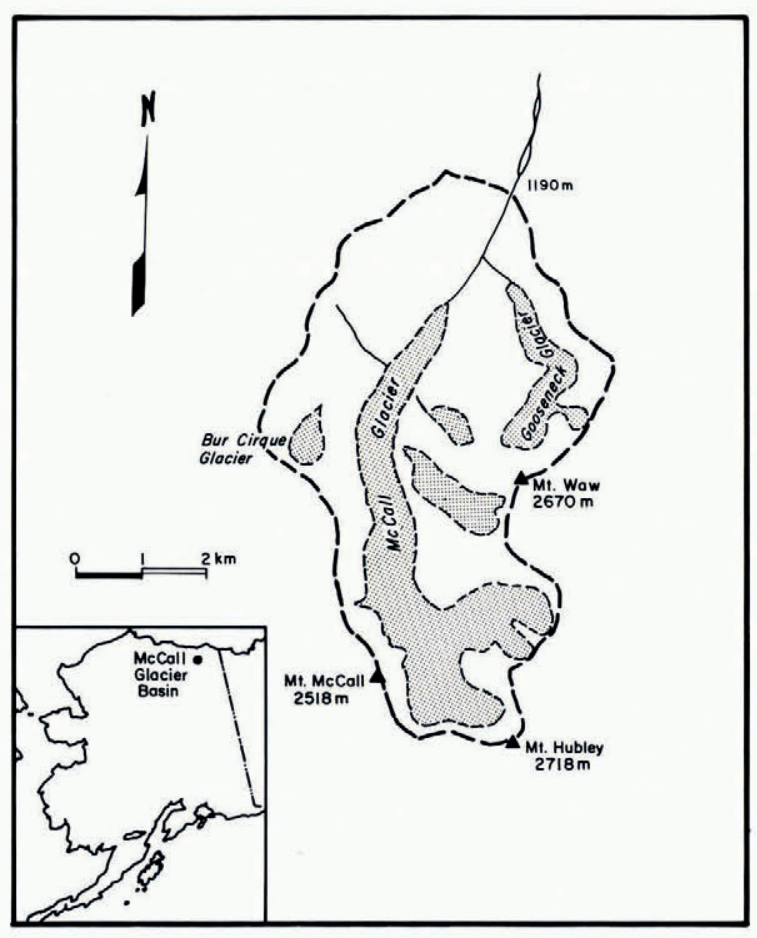

Fig. 1. Location map of the McCall Glacier basin.

the error in the accuracy of the evaluation as compared with the actual change of the glacier may be disproportionally large.

In the summer of $195^{8}$, as part of the I.G.Y. program, aerial photogrammetric pictures on a scale of I : 24000 were obtained of McCall Glacier, which resulted in a 1 : 10 ooo scale map with $5 \mathrm{~m}$ contours (Case, I 958). In the summer of $197 \mathrm{I}$ we repeated the photogrammetric flight (Fig. 2) this time with color photography at a scale of $1: 20000$ mainly for reasons of better interpretability. The time lapse of 13 years between $195^{8}$ and $197 \mathrm{I}$ was considered to be sufficient for a quantitative determination of glacier height changes. Normally, such changes are found indirectly by comparing two contour maps of the same region, but compiled from photographs taken at two different times ("topographic" method). The fact that no ground control data were available from 1958, and that the glacier height changes might be less than expected, i.e. less than about $5 \mathrm{~m}$, made it advisable to establish, survey, and signalize a completely new ground control. High accuracy could only be obtained by evaluating the new photographs together with the old ones, viz. via identical features or points.

During July and August I97 I a local three-dimensional triangulation network consisting of some 30 stations was observed by a group of three persons. Angle measurements were carried out with a Wild $\mathrm{T}_{2}$ theodolite, the scale was determined by some ten distances measured with a Hewlett-Packard $3800 \mathrm{~B}$ distance meter. Ten stations were signalized by crosses 2-3 $\mathrm{m}$ long laid out with fluorescent red plastic material. The accuracy obtained after a simultaneous least-squares adjustment of the network (Amaresekere, 1972) showed mean standard errors of $0.2 \mathrm{~m}$ for the horizontal coordinates and $0.15 \mathrm{~m}$ for the elevations. 


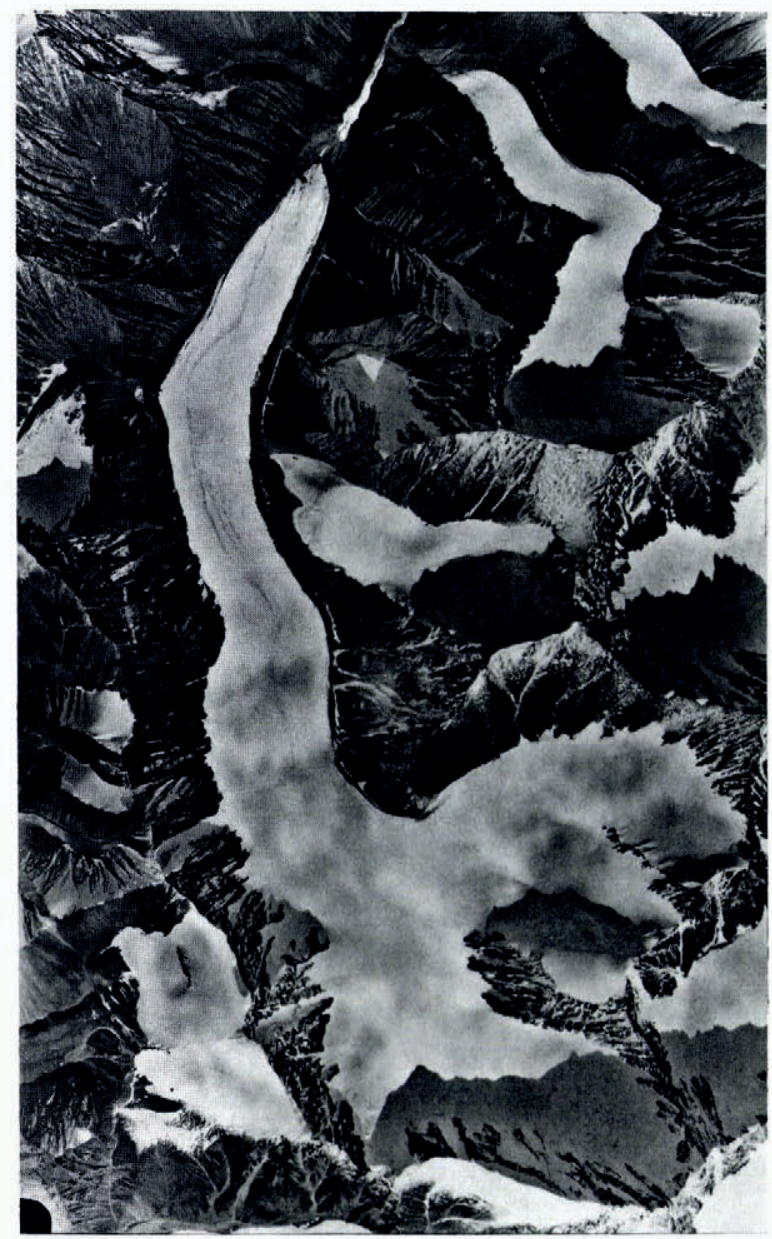

Fig. 2. Aerial photo-mosaic of McCall Glacier, $197 \mathrm{I}$.

Due to poor third generation quality of the $195^{8}$ photography, and completely missing camera calibration data*, only a purely "analytical" method could be considered as giving sufficiently accurate results. A variety of solutions to this so-called block-analytical aerial triangulation do exist and are commonplace in photogrammetric practice (e.g. Brown, 1973). Systematically overlapping photographs are related to each other by means of transfer points. As the image contrast on the $195^{8}$ photographs was extremely poor, particularly on the glacier surface (Fig. 3), since rather different illumination effects and snow coverage prevailed during the two photo missions, and since the photo scales differed by about $20 \%$, it was virtually impossible to locate a sufficient number of transfer points between the 1958 and i97 i photographs. We therefore decided to make use of a rigorous stereo-block analytical triangulation similar to a suggestion published by Albertz (1972). No transfer points are required with this method, but possibly all overlapping photographs must be measured stereoscopically in a

* The U.S. Air Force detachment keeping the original negatives had been dissolved recently. 

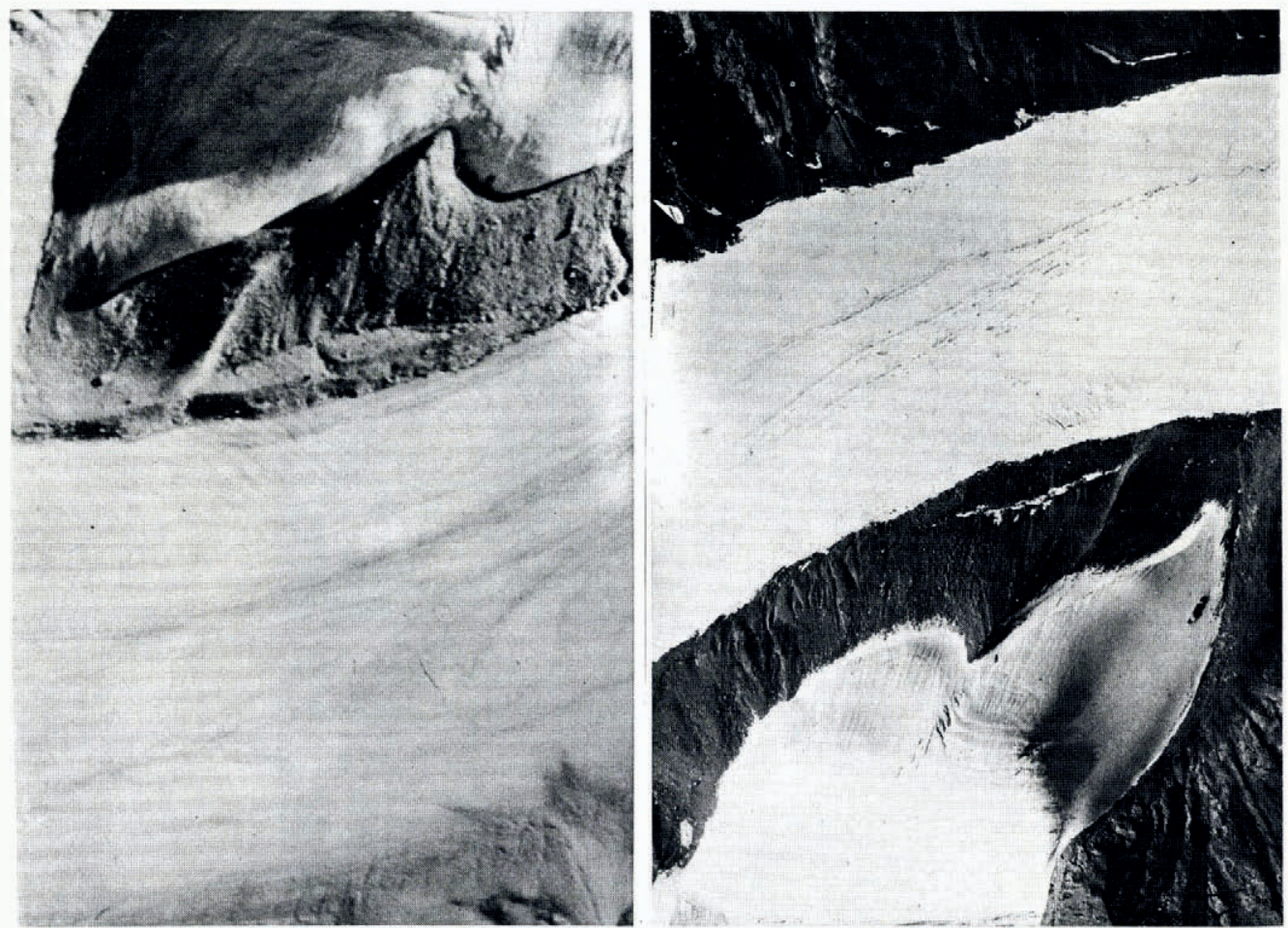

Fig. 3. (a) Einlarged section of 19.58 photography (left). (b) Enlarged section of 19;1 photography (right).

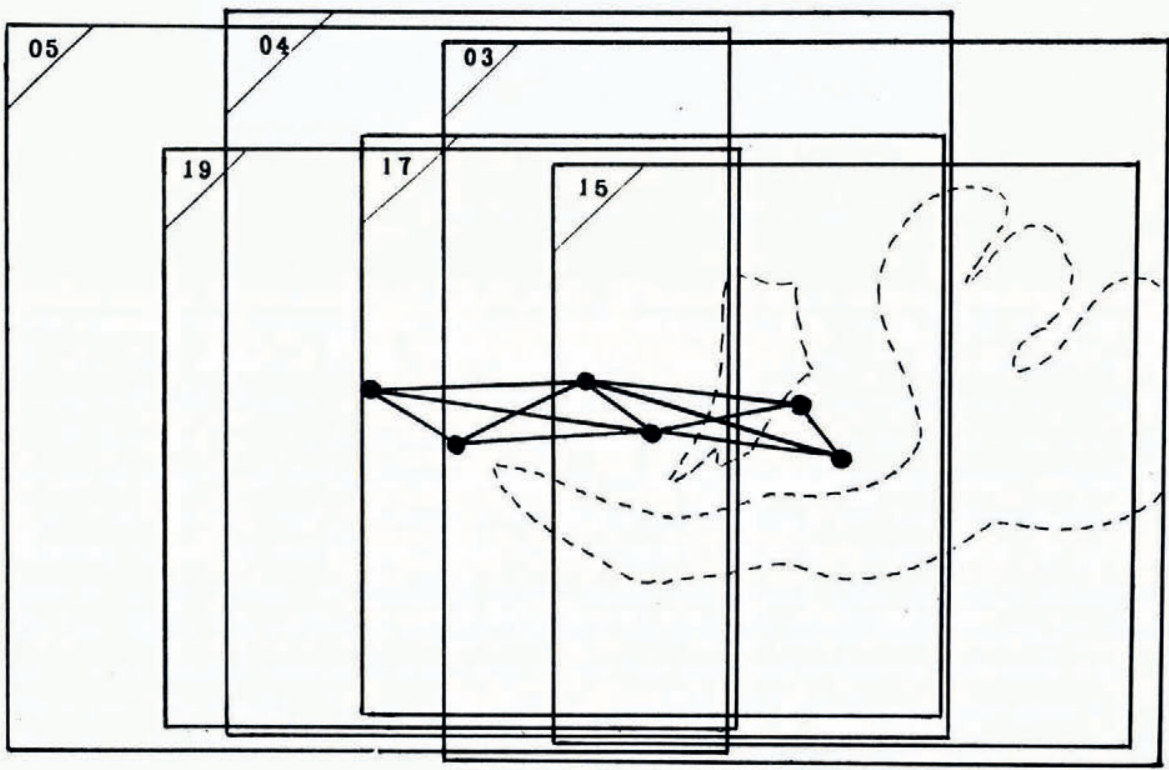

Fig. 4. Schematic photographic coverage of McCall Glacier area for stereo block analytical triangulation. 19.58 photographs 05, 04, 03; scale I: 24000 . 197 I photographs 19, I7, 15; scale 1: 20000. 
stereo comparator. Figure 4 shows the geometric configuration of the $2 \times 3$ photographs selected for this project. The straight lines connecting the six camera stations indicate that in total eleven stereopairs were measured, viz. two pairs with $195^{8}$ photos, two pairs with I97 I photos, and seven pairs with combined 1958/1971 photographs. The actual photogrammetric solution is described in Dorrer (1975).

The camera stations and exterior and-for the $195^{8}$ photos - interior orientation parameters are related to each other by means of three types of non-linear condition equations, viz. a coplanarity condition for each pair of measured points, a control condition for each measured control point, and a transfer condition for a measured reference point. In a first phase, an iterative simultaneous least-squares procedure was used to solve for the 32 unknown parameters. A total of $5_{1} 6$ points were measured stereoscopically, viz. control points, stereo-pair points, glacier points, and a few reference points on bedrock close to the glacier for eliminating or reducing local systematic error sources (bias) inherent in the two types of photographs. Already at this stage it became clear that, due to poor contrast conditions, only a few regions on the glacier surfaces were suited for selecting measurable glacier points. The néve region was entirely unsuitable due to snow coverage of the 1971 photographs.

The second phase of the procedure consisted of intersecting spatially all control, glacier, and pass points. The residual $y$-parallaxes* agreed very well with random variables taken from a normally distributed population. As expected, for the $195^{8}$ photographs, the rootmean-square values are roughly twice as large $(0.85 \mathrm{~m})$ as for 1971 ( $0.40 \mathrm{~m})$. Though not determined explicitly, corresponding elevation errors are of the same order of magnitude.

In its third phase, the procedure performed an absolute orientation into the given ground control. An existing computer program (Ackermann and others, 1970) was used, which resulted in surprisingly small root-mean-square values for the coordinate residuals of all control points, viz. $0.15 \mathrm{~m}$ for $X, 0.21 \mathrm{~m}$ for $r$, and $0.14 \mathrm{~m}$ for $Z$ (1971 photography only). For an average flying height of $3000 \mathrm{~m}$, the relative elevation error is thus below $0.5 \times 10^{-4}$. This accuracy could have never been achieved by a purely topographic method.

The last phase was to determine representative glacier elevation changes for a few characteristic cross-sections. It was intended originally to describe the glacier surfaces by twodimensional polynomials and to condense all information into one value for each cross-section, thus averaging out many error sources. This method, however, failed due to poorly ordered and unfavorably related point distributions on the glacier surfaces. Instead all measured glacier points and reference points were plotted on a scale of $\mathrm{I}: 10 \mathrm{ooo}$, and, by manual and graphical' procedures only, spot heights of the two glacier surfaces were corrected for local bias (reference points), and related to each other.

The results of the graphical method were improved by a numerical procedure. For each of the three glacier regions at least four reference points were carefully selected. Their elevation differences $\Delta Z$ were used to interpolate a least-squares bi-linear trend surface. The elevations of glacier points were corrected prior to comparing the two glacier surfaces represented by unordered sets of spot heights. The standard error of glacier elevation change is a function of its position. Computed values for each region can be considered representative for the final elevation changes shown in Table I. The standard errors $\sigma_{\Delta} z$ are representative for a single elevation difference average over each of the regions. Since for each region a single elevation change $\Delta Z$ was determined from several interpolated spot heights, the actual standard error for the meaned height change is smaller. Assuming no further bias, the standard errors $\bar{\sigma}_{\Delta z}$ of the mean may be considered around $0.5 \mathrm{~m}$ (last row in Table I). The quantity $\sigma_{0}$ represents the standard error of an original reference point elevation difference prior to eliminating a local bi-linear bias.

* The $y$-parallax is a measure for the degree of non-intersection of two spatial rays. 
Table I. Glacier elevation changes i $95^{8}-71$ as determined by aerial PHOTOGRAMMETRY

\begin{tabular}{lccc}
\multicolumn{1}{c}{ Region } & 1 & 2 & 3 \\
Mean altitude $Z$ & $1500 \mathrm{~m}$ & $1715 \mathrm{~m}$ & $1900 \mathrm{~m}$ \\
Elevation change $\Delta Z$ & $4.5 \mathrm{~m}$ & $2.9 \mathrm{~m}$ & $2.0 \mathrm{~m}$ \\
Number of interpolated spot heights $n$ & 6 & 8 & 5 \\
Mean deviation & $1.0 \mathrm{~m}$ & $1.4 \mathrm{~m}$ & $1.0 \mathrm{~m}$ \\
Number of reference points & 5 & 7 & 4 \\
Standard error of elevation change $\sigma_{0}$ & $0.7 \mathrm{~m}$ & $2.6 \mathrm{~m}$ & $0.7 \mathrm{~m}$ \\
Standard error of regional average $\sigma \Delta z$ & $0.9 \mathrm{~m}$ & $1.7 \mathrm{~m}$ & $0.9 \mathrm{~m}$ \\
Standard error of mean $\bar{\sigma} \Delta z=\sigma \Delta z / 1 \mathrm{n}$ & $0.4 \mathrm{~m}$ & $0.6 \mathrm{~m}$ & $0.4 \mathrm{~m}$
\end{tabular}

In addition, Figure 5 shows a reasonable exponential curve interpolated into the three regional elevation changes. The $\sigma$-confidence band indicates, however, that extrapolating the elevation changes beyond an altitude of $2100 \mathrm{~m}$ gives rise to rather large uncertainties, and may lead to wrong conclusions.

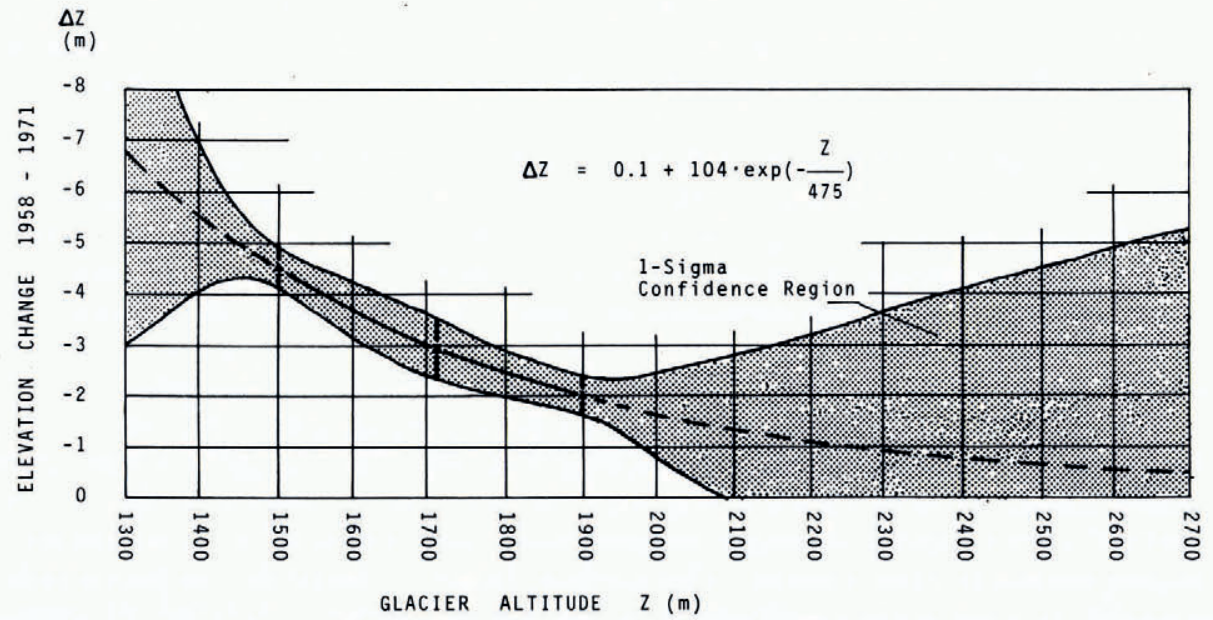

Fig. 5. Elevation change of McCall Glacier obtained from aerial photogrammetry in $19.5^{-8}$ and $197^{\prime}$ plotted as a function of glacier altitude.

Using this regression curve, the glacier became in the mean $185 \mathrm{~cm}$ thinner, which represents a loss of $1 \mathrm{r} .6 \times \mathrm{IO}^{6} \mathrm{~m}^{3}$ ice or snow. This would result in a mean annual balance of - I $28 \mathrm{~mm}$ water equivalent for the $\mathrm{I} 3$ year period. For this calculation it was assumed, that the mass loss was all ice of density $0.9 \mathrm{Mg} \mathrm{m}^{-3}$. This assumption should be reasonable, as the photogrammetric overflights were both made at about the same time in summer and the total amount of snow on the glacier may well have been similar. However, if part of the amount lost had consisted of snow or firn, a mean annual mass balance somewhat nearer to zero would have been found.

\section{Chimatology}

Hoinkes (197I) has shown that it is possible to obtain a good estimate of the mass balance of a glacier by using the climatological data of a nearby valley station. Using the massbalance data of the Hintereisferner, Austria, and the climatological data of the valley station Vent, he established so called $T S$ functions ( $T=$ temperature, $S=$ snow). Basically, temperature summations were used after applying a correction for the altitude difference 
between the station and the glacier. These were then corrected for snowfall which occurred during the summer. Owing to its high albedo, the snowfall retards the ablation substantially (Tronov, 1962). The relationships he found are good. Initially this is surprising, since the ablation on a glacier is mostly caused by radiation and not by sensible heat (e.g. Hoinkes, I964; Wendler and Weller, I974). However, there exists a good relationship between the radiation balance and the temperature, which means that a sunny day with a positive radiation balance is also normally warmer than a cloudy day with a less positive radiation balance. Ambach (1972) and Dreiseitl (unpublished) have successfully used the method developed by Hoinkes.

The nearest climatological station from McCall Glacier was Barter Island, about i io km to the north of the glacier. Arctic Village, some $160 \mathrm{~km}$ to the south, had poor and irregular records, and Fairbanks, more than $500 \mathrm{~km}$ to the south, was considered to be too far away.

An attempt was made to apply the method developed by Hoinkes for the relationship between the mass balance of McCall Glacier and the climatological data of Barter Island. Although several variations of this method were applied, no relationship could be established. To discover if there was any relationship between the climatological data of Barter Island and the mass balance on McCall, the daily mean temperatures at Barter Island were plotted against the daily values of ice ablation (Fig. 6). The ice ablation data were obtained as the mean measurements of ten small ablation stakes at I $740 \mathrm{~m}$ altitude, carefully read twice daily. It can be seen, that no well-established relationship exists and no further attempt was made to

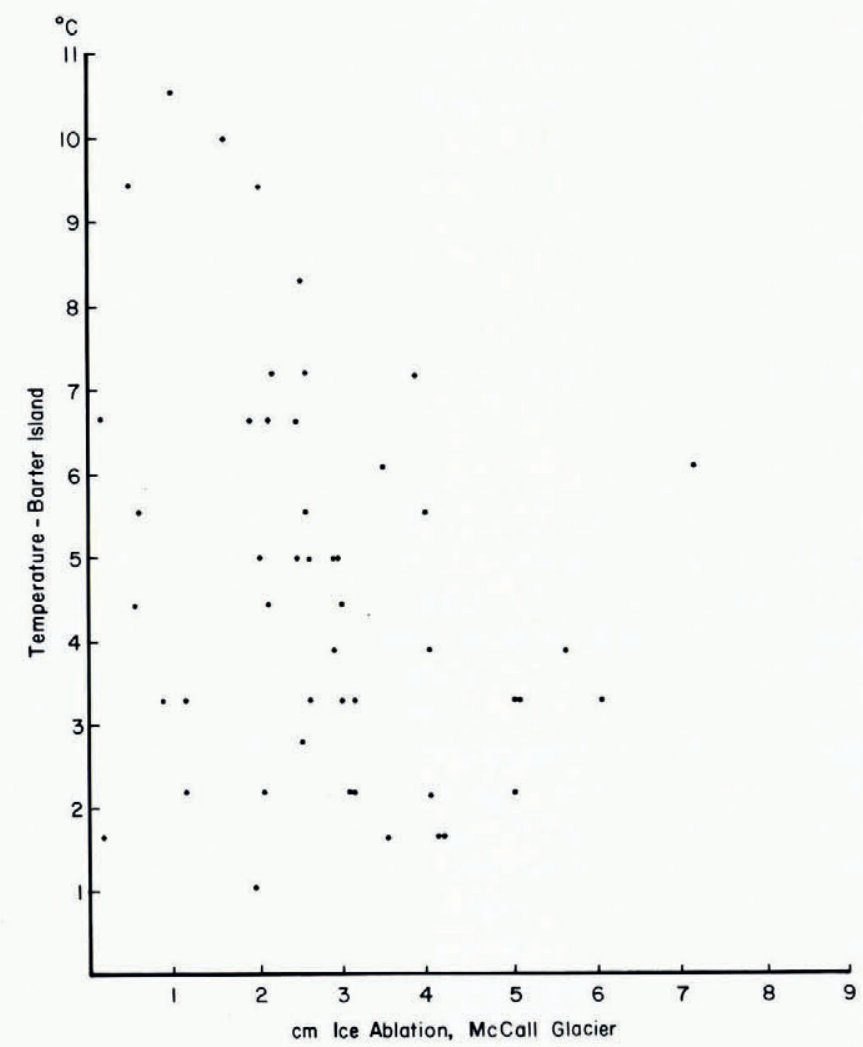

Fig. 6. Daily amount of ice ablation on McCall Glacier at $1740 \mathrm{~m}$ (the mean ialue from ten ablation stakes) plotted against the daily mean temperature at Barter Island, $110 \mathrm{~km}$ to the north. 
use the Barter Island climatological data to obtain estimates of the mass balance of McCall Glacier. The result suggests that the climate of McCall Glacier is substantially different from that of Barter Island. This has been shown elsewhere by Wendler and others (1974). McCall Glacier lies on the divide of the continental climate of interior Alaska and the Arctic climate of the slope, while Barter Island is primarily under the influence of the climate of the Arctic Ocean (Searby, ig68).

\section{Height of annual equilibrium line and mass balance}

During our field work on McCall Glacier between 1969 and 1972, two I.G.Y. ablation stakes were found at an altitude of about $2065 \mathrm{~m}$. These stakes had neither melted out of the ice nor been covered by the snow during the period from $195^{8}$. This means that over this time period this location had to be, on the average, near the annual equilibrium line of the glacier.

Several authors (e.g. Palgov, 1962; Meier and Post, I962; Wendler, 1967) have shown that there is a linear dependence between mass balance and the AAR, or, equivalently, between the mass balance and the height of the equilibrium line. Using this relationship and considering the movement of the glacier of about $10 \mathrm{~m}$ per year, a mean mass balance of $-265 \mathrm{~mm}$ per year could be calculated. However, one has to be somewhat careful with this value. The stakes were just penetrating through the surface when found. We do not know, how far the stake had been exposed above the glacier surface in the summer of I958. If, at that time, the stake had been exposed to its full length $(4-5 \mathrm{ft}, \mathrm{I} .2-1.5 \mathrm{~m})$, which would be the other extreme, the mass balance would be less negative by about $100 \mathrm{~mm}$ water equivalent and values of about $-165 \mathrm{~mm}$ per year would be found.

\section{Height of the 5 oo mbar level and mass balance}

Schneider (unpublished), Hoinkes and others (1968), Fahl (unpublished), and Dreiseitl (unpublished) have shown that there is a relationship between the height of the 500 or 700 mbar synoptic pressure level in summer and the mass balance. A negative deviation from the mean in the height means cool weather with precipitation which is "healthy" for the glacier, while a positive deviation means sunny weather with increased ablation, which is hence "unhealthy" for the glacier.

For the four years in which detailed mass-balance data were available, the mass balance was plotted against the deviation from the mean of the 500 mbar level for McCall Glacier in summer. However, the relationship found was not very good. This is understandable, as two factors influence the annual mass balance. The first is the ablation in summer, for which the deviation of the 500 mbar level might be a good indicator; the second is the accumulation throughout the year for which this value is not a good indicator. The mass balance value was therefore corrected for a precipitation deviation from the mean. Wendler and others ( 1974 ) showed that the precipitation at McCall Glacier (about $500 \mathrm{~mm}$ ) is about three times higher than that of Barter Island (long-term mean $160 \mathrm{~mm}$ ). Despite the shortcomings of Barter Island as a guide to the McCall climate, a first approximation of the precipitation deviation could perhaps be made by using three times the precipitation deviation at Barter Island. This assumes that all precipitation falls in solid form, which is generally true for McCall Glacier even in midsummer.

For the deviation from the mean of the 500 mbar level, June and July were given twice the importance of May and August. The ablation season, lasting about three months, is short on McCall Glacier (Trabant and others, unpublished), and June and July contribute most to the melt, with less melt occuring in May and August. A similar method was used by Hoinkes and others (1968). 


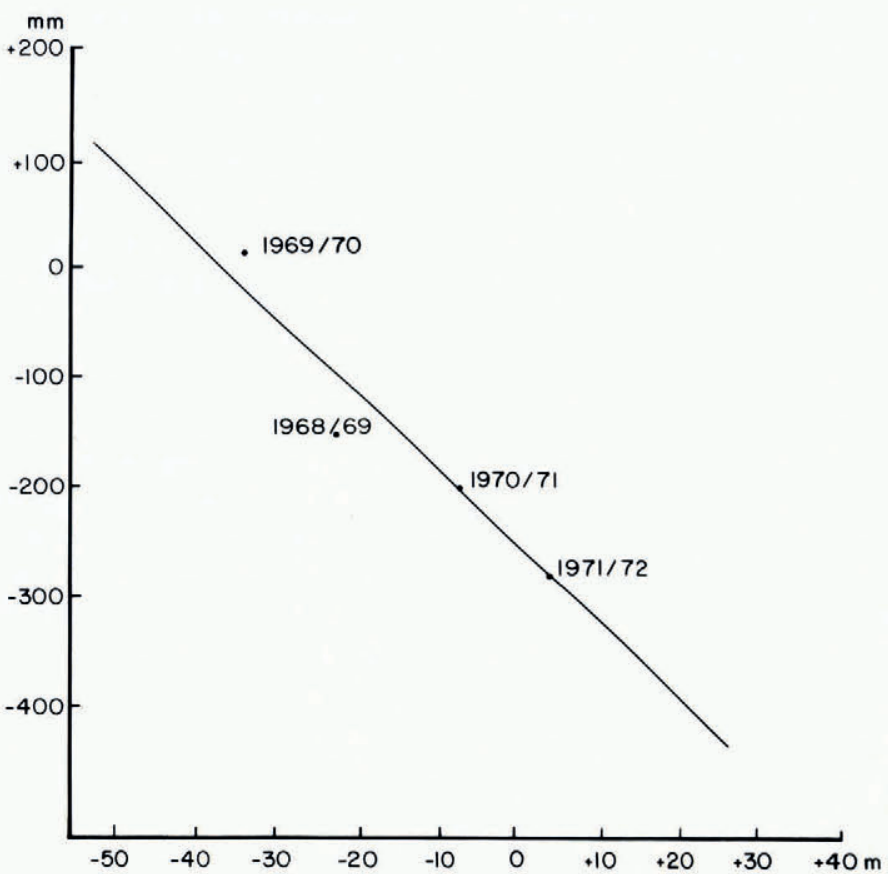

Fig. 7. The deviation from the mean height of the 500 mbar level in meters for summer plotted against the specific mass balance of McCall Glacier. The mass-balance values were corrected for anomalies in the precipitation for the hydrological years by applying the Barter Island data. The summer deviations of mean height are found by adding the values for May and August and twice the values for June and July and dividing the sum by six.

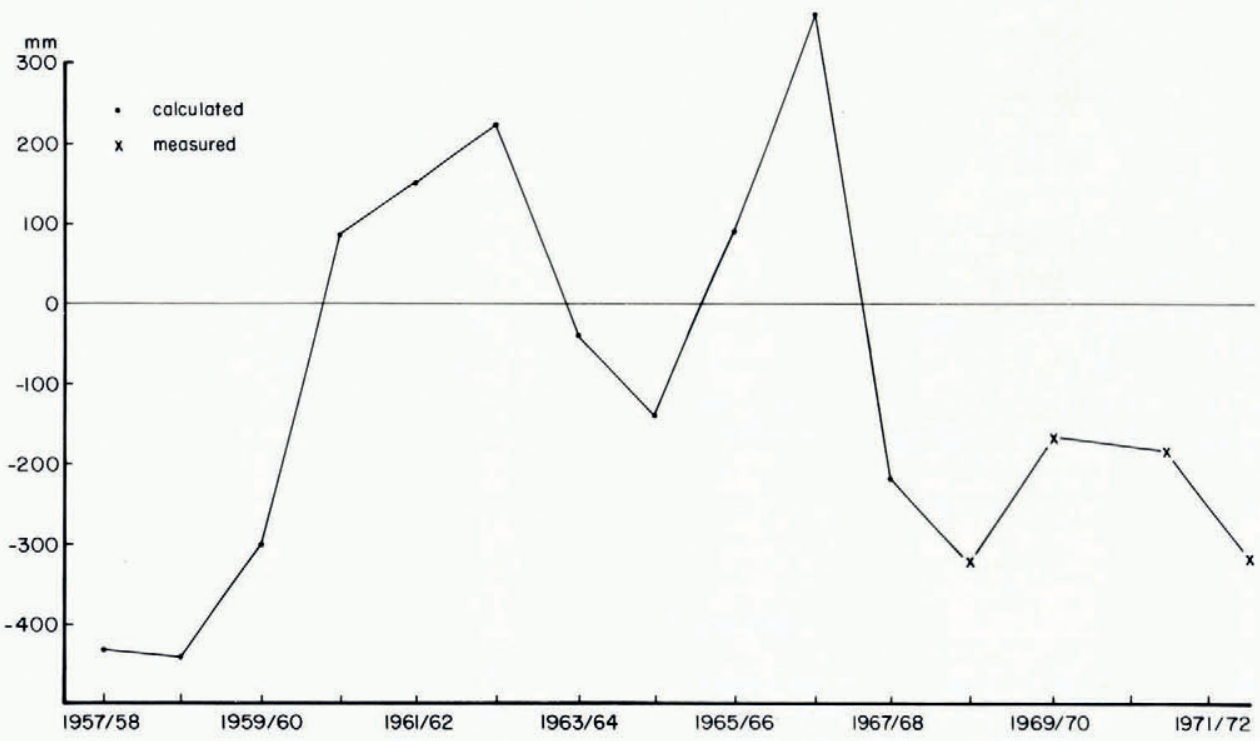

Fig. 8. The calculated mass balance of McCall Glacier, using the relationship between the height of the 500 mbar level and the mass balance (Fig. 7). 
If the corrected mass-balance figures are plotted against the deviations of the 500 mbar level, a relatively good relationship is found (see Fig. 7). The mean difference in the mass balance between observed and calculated values is $22 \mathrm{~mm}$, a relatively small amount.

Using this relationship, the mass balance could be calculated back to I957 (see Fig. 8). One can see that the period $1961-67$ had positive or only slightly negative values, which is in agreement with Fahl (1973). Altogether, the negative values dominate, a mean mass balance of $-94 \mathrm{~mm}$ per year being found for the period $195^{8-71}$ by this method. This means that the glacier became thinner on the average by $1.36 \mathrm{~m}$ of ice or lost a total mass of $7.6 \times 10^{6} \mathrm{~m}^{3}$ water.

\section{Cionclusion}

Calculation of the mass balance of McCall Glacier using different methods showed that the glacier has lost mass for the period $195^{8-7 I}$ (Table II). The actual values are relatively small; one should consider, however, that annual ablation and accumulation rates are much smaller there than at lower latitudes. This trend of glacier retreat seems to be typical and has apparently been going on for a long time in the Brooks Range. Sable (196r) reported that the Opilak Glacier, about ${ }_{1} 5 \mathrm{~km}$ to the south-west, had been receding for 50 years $\left(1907-5^{8}\right)$.

$$
\begin{array}{lrr}
\text { TABle II. Estimates OF } & \text { THE } \\
\text { SPECIFIC MASS BALANCE } & \text { OF } \\
\text { MCCALL GLACIER, FOR } & \text { THE } \\
\text { PERIOD I } 95^{8} \text { To I } 97 \mathrm{I} & \\
& \mathrm{mm} \\
& & -128 \\
\text { Photogrammetry } & \mathrm{a}-265 \\
\text { Equilibrium line } & \mathrm{b}-165 \\
\text { 50o mbar level } & & -95
\end{array}
$$

Further, he found that the rate of depletion had increased since i 950. Hamilton (1965) found that glaciers in the south-central Brooks Range had been receding for at least 50 years (191 1-62). This trend of glacier retreat for the last 50-6o years found in the Brooks Range agrees well with the simultaneous retreat of the majority of the glaciers in the Northern Hemisphere (Grosval'd and Krenke, 1962; Meier, 1965; Hoinkes, 1968, and Meier and others, I971).

\section{AGKnowledgement}

The research was supported by the Atmospheric Science Section, National Science Foundation, under Grants GA-37306 and DES 75-06i84. We would like to thank our colleagues and students who helped with the field work. Professor N. Streten read this manuscript, and made many valuable comments, for which we are thankful.

MS. received 22 September 1975 and in revised form 2 February 1976

\section{REFERENCES}

Ackermann, F.. and others. 1970. Ein Programmpaket für die Aerotriangulation mit unabhängigen Modellen, von F. Ackermann, H. Ebner und H. Klein. Bildmessung und Luftbildwesen, Bd. 38, Ht. 4, p. $218-24$.

Albertz, J. 1972. Blocktriangulation ohne Punktübertragung. Bildmessung und Luftbildwesen, Bd. 40, Ht. 1, p. $38-40$.

Ambach, W. 1972. Zur Schätzung der Eis-Nettoablation im Randgebiet des grönländischen Inlandeises. Polarforschung, Bd. 7, 42. Jahrg., Nr. I, p. $18-23$. 
Ameresekere, R. S. S. 1972. Adjustment of the McCall Glacier survey 197I. Fredericton, N.B., University of New Brunswick. (Master of Engineering Report.)

Brown, D. C. 1973. Accuracies of analytical triangulation in applications to cadastral surveying. Surveying and Mapping, Vol. 33 , No. 3, p. 281-302.

Case, J. B. 1958. Mapping of glaciers in Alaska. Photogrammetric Engineering, Vol. 14, No. 9, p. 81 $5^{-21}$.

Dorrer, E. 1975. Contribution to a general stereoscopic block analytical aerotriangulation. Deutsche Geodätische Kommission, Reihe B, Nr. 214, p. 125-36.

Dreiseitl, E. Unpublished. Witterungsklimatologie von Vent und Massenbilanz des Hintereisferners $1955^{-1} 1971$. [Dr. phil. thesis, Universität Innsbruck, 1973.]

Fahl, C. B. Unpublished. Some relationships between glaciers and climate in Alaska. [Ph.D. thesis, University of Alaska, i973.]

Finsterwalder, R. 1953. Die zahlenmässige Erfassung des Gletscherrückganges an Ostalpengletschern. Zeitschrift für Gletscherkunde und Glazialgeologie, Bd. 2, Ht. 2, p. 189-239.

Grosval'd, M. G., and Krenke, A. N. 1962. Recent changes and the mass balance of glaciers on Franz Josef Land. Union Géodésique et Géophysique Internationale. Association Internationale d'Hydrologie Scientifique. Commission des Neiges et des Glaces. Colloque d'Obergurgl, $10-9-18-91962$, p. $194-200$.

Hamilton, T. D. 1965. Comparative glacier photographs from northern Alaska. Journal of Glaciology, Vol. 5. No. 40, p. $479^{-87}$.

Hoinkes, H. C. 1964. Glacial meteorology. (In Odishaw, H., ed. Research in geophysics. Vol. 2. Solid earth and interface phenomena. Cambridge, Mass., MIT Press, p. 391-424.)

Hoinkes, H. C. 1968. Das Eis der Erde: weltweite Forschungsprogramme in der Internationalen Hydrologischen Dekade. Umschau in Wissenschaft und Technik, 1968, Ht. 10, p. $301-06$.

Hoinkes, H. C. 1971. Über Beziehungen zwischen der Massenbilanz des Hintereisferners (Ötztaler Alpen, Tirol) und Beobachtungen der Klimastation Vent. Annalen der Meteorologie, Neue Folge, Nr. 5, p. $259-64$.

Hoinkes, H. C., and Rudolph, R. 1962. Variations in the mass-balance of Hintereisferner (Ötztal Alps), r9521961 , and their relation to variations of climatic elements. Union Géodésique et Géophysique Internationale. Association Internationale d'Hydrologie Scientifique. Commission des. Neiges et des Glaces. Colloque d'Obergurgl, 10-9-18-9 I.962, p. $16-28$.

Hoinkes, H. C., and others. 1968. Glacier mass budget and mesoscale weather in the Austrian Alps 1964 to 1966 , by H. C. Hoinkes, F. Howarka and W. Schneider. Union de Géodésie et Géophysique Internationale. Association Internationale d'Hydrologie Scientifique. Assemblée générale de Berne, 25 sept.-7 oct. 1967 . [Commission de Neiges et Glaces.] Rapports et discussions, p. 241-54.

Keeler, C. M. 1959. Notes on the geology of the McCall Valley area. Arctic, Vol. 1 2, No. 2, p. 87-97.

LaChapelle, E. R. ${ }^{1965}$. The mass budget of Blue Glacier, Washington. Journal of Glaciology, Vol. 5. No. 41. p. 6o9-23.

Mason, R. W. 1959. The McCall Glacier project and its logistics. Arctic, Vol. 12, No. 2, p. 77-81.

Meier, M. F. ${ }^{1965 . ~ G l a c i e r s ~ a n d ~ c l i m a t e . ~(I n ~ W r i g h t, ~ H . ~ E . . ~ j r ., ~ a n d ~ F r e y, ~ D . ~ G ., ~ e d . ~ T h e ~ Q u a t e r n a r y ~ o f ~ t h e ~ U n i t e d ~}$ States. Princeton, Princeton University Press, p. 795-805.)

Meier, M. F., and Post, A. S. 1962. Recent variations in mass net budgets of glaciers in western North America. Union Géodésique et Géophysique Internationale. Association Internationale d'Hydrologie Scientifique. Commission des Veiges et des Glaces. Colloque d'Obergurgl, Io-9 I8-9 1962, p. 63-77.

Meier, M. F., and Tangborn, W. V. I965. Net budget and flow of South Cascade Glacier, Washington. Journal of Glaciology, Vol. 5, No. 41, p. 547-66.

Meier, M. F., and others. I 971 . Ice and water balances at selected glaciers in the United States. Ciombined ice and water balances of Gulkana and Wolverine glaciers, Alaska, and South Cascade Glacier, Washington, I 965 and 1966 hydrologic years, by M. F. Meier, W. V. Tangborn, L. R. Mayo and A. [S.] Post. U.S. Geological Survey. Professional Paper 715-A.

Orvig, S., ed. 1961. McCall Glacier. Alaska: meteorological observations, 1957-1958. Arctic Institute of . Porth America. Research Paper No. 8.

Orvig, S., and Mason, R. W. 1963. Ice temperatures and heat flux, McCall Glacier, Alaska. Union Géodésique et Géophysique Internationale. Association Internationale d'Hydrologie Scientifique. Assemblée générale de Berkeley. $19-8-31-81963$. Commission des. Veiges et des Glaces, p. $181-88$.

Pal'gov, N. N. r 962 . The relation between glacier retreat and position of the firn line with special reference to the Zentralny Tuyuksu Glacier. Union Géodésique et Géophysique Internationale. Association Internationale d'Hydrologie Scientifique. Commission des. Veiges et des Glaces. Colloque d'Obergurgl, 10-9-18-9 1962, p. 40-48.

Paterson. W. S. B. ${ }^{1} 969$. The physics of glaciers. Oxford. Pergamon Press. (The Commonwealth and International Library. Geophysics Division.)

Sable, E. G. 1961. Recent recession and thinning of Okpilak Glacier, northeastern Alaska. Arctic, Vol. 14 , No. 3. p. $176-87$.

Sater, J. E. 1958. Surface motion studic's on the McCall Glacier, June to October 1957. I.G.Y. Glaciological Report Series (New York, I.G.Y. World Data Center A, Glaciology), No. 1, p. xii-4-10.

Sater, J. E. 1959. Glacier studies of the McCall Glacier, Alaska. Arctic, Vol. i2, No. 2, p. 82-86.

Schneider, W. Unpublished. Ober Beziehungen zwischen den Massenhaushalten der Gletscher und der allgemeinen Zirkulation. [Dr. phil. thesis, Universität Innsbruck, 1967.]

Schytt, V. 1962. Mass balance studies in Kebnekajse. Journal of Glaciology, Vol. 4. No. 33. p. $281-88$.

Searby, H. W. 1968. Climates of the States. Alaska. Washington. D.C., U.S. Weather Bureau. (Climatology of the United States, 6o-49.)

Trabant, D. C., and others. Unpublished. Mass balance and superimposed ice formation on McCall Glacier, Brooks Range, Alaska, I971 and 1972 hydrologic years: a contribution to the International Hydrological Decade, by D. [C.] Trabant, C. [B.] Fahl and C. [S.] Benson. 
Tronov, M. V. 1962. On the role of summer snowfall in glacier variation. Union Géodésique et Géophysique Internationale. Association Internationale d'Hydrologie Scientifique. Commission des. Veiges et des Glaces. Colloque d'Obergurgl. $10-9-18-91962$, p. 262-69.

Wendler, G. 1967. Die Vergletscherung in Abhängigkeit von Exposition und Höhe und der Gebietsniederschlag im Einzugsgebiet des Pegels Vent in Tirol. Archiv für Meteorologie, Geophysik und Bioklimatologie, Ser. B, Bd. I5, Ht. 3, p. $260-73$.

Wendler, G., and Weller, G. 1974. A heat-balance study on McCall Glacier, Brooks Range, Alaska: a contribution to the International Hydrological Decade. Fournal of Glaciology, Vol. ${ }_{1} 3$, No. 67, p. ${ }_{13}-26$.

Wendler. G., and others. 1972. Mass balance studies on McCall Glacier, Brooks Range, Alaska. [by] G. Wendler, C. [B.] Fahl and S. Corbin. Arctic and Alpine Research. Vol. 4, No. 3. p. $211-22$.

Wendler, G., and others. 1974. The climate of the McCall Glacier. Brooks Range, Alaska, in relation to its geographical setting, |by] G. Wendler, N. Ishikawa and N. [A.] Streten. Arctic and Alpine Research, Vol. 6, No. 3 , p. $307^{-1} 8$. 